\title{
Sports Sponsorship Development Company: Image and Creating Competitive Advantage
}

\author{
Mokhalles M Mehdi*
}

\section{Abstract}

Companies are using sports-sponsorship to enhance the image of their products and to create competitive advantage in the market in-terms of uniqueness. Considering the example of competitive advantage, Nike in design, FedEx in quick delivery, and Wal-Mart in low price, the objective of the study is to investigate the effect of sport-sponsorship technique on brand image and the competitive advantage. In addition, the study will identify the relationship between celebrity endorsements and how the endorsements have an impact on buying behavior. The study covers both the primary investigation and secondary literature review. Data was collected with help of structured questionnaire and analyzed by using several statistical techniques such as Chi-Square test, Paired t-Test and Regression analysis (used to identify the relationship between sports celebrity endorsements and buying behavior). Research has indicated that live broadcast of sport sponsorship gets the favour of the respondent. Research has revealed that companies should prefer advertising as a sport-sponsorship technique to increase the brand awareness. Findings of the study indicate that for advertising, companies need to be cautious while selecting other medium of sponsorship. The study concludes that there is a relationship between sports celebrity endorsement and consumer buying behavior.

* Assistant Professor of Marketing, MIS \& IT, The Assam Kaziranga University, Koraikhowa, NH 37, Jorhat, Assam, India; mokhalles@kazirangauniversity.in 
Keywords: Sponsorship, Sports, Brand, Corporate image, Competitive Advantage

\section{Introduction}

In recent times, sponsorship is the key tool of marketing communication and brand building. Based on the approach of marketing communication, sponsorship can be divided into three wide categories: Corporate, Marketing and Philanthropic. Among these, marketing sponsorship is widely used by the companies. Marketing sponsorships are frequently used by companies as a mode of advertising or brand promotion to ascertain brand identification. It provides the opportunity for an organization to form a bond of association with the customers by using several media such as sport sponsorship, event sponsorship and roadshows. Sports sponsorship's exponential augmentation in the area of brand promotion and communication in contemporary times has attracted the academicians to study the effect of sponsorships in different events.

Meenaghan (1994) indicated in his research that sponsorship is an investment in the team, player or an event to associate commercially to increase the visibility and top line of the company. Companies do the sponsorship to increase the appeal of their brand in the market. Considering the example of Nike, sponsorship is used as a superior resource like basketball superstar Michael Jordan to produce a sustainable competitive advantage. During a careful promotional campaign Nike made its "Air Jordan" range of athletic footwear the biggest selling athletic shoe of all time.

Business endorsement is a venture in cash to return the access to the usable commercial connected with the activity (Meenaghan, 1991). The purpose of collaborating with different companies regarding sponsorship agreement fluctuates with respect to the need and resource of a company. The most important objective of sponsoring companies is to increase the awareness of firm or brand among customers and augment the image of company or brands (Witcher, Craigen, Culligan \& Harvey, 1991); Meenaghan, 1991; Mintel, 1994). 
Big multi-national companies such as Coca-Cola, Pepsi-co, Hero Honda Motors Ltd., L.G. Electronics and Adidas are sponsoring in the sports including Cricket, Football and Lawn Tennis etc. to develop their company image and also to create a sustainable competitive advantage.

\section{Objective of the Study}

The key objective of the research is to examine the effect of sports sponsorship technique on brand image and competitive advantage. The study aims to identify the relationship between celebrity endorsements and buying behaviour (analyzed using regression equation analysis).

\section{Methodology}

Sports-sponsorship is used to enhance the company image and also to create the competitive advantage. In the present scenario, satellite television, changing lifestyles, increasing advertisement and demand for superior quality of products have influenced the buying behavior of the customers as well as to attract more and more customers. Therefore to know how much effect on customer's behavior is done by the companies like Coca-Cola, Pepsi, Adidas, LG and Hero Honda by using their Sports-sponsorship strategy.

An exploratory study was carried out to get clarity of the statement of the problem, by interacting with customers/consumers to understand their interest in sports-sponsorship of the company and its competitive advantage. It was found that there are so many factors that influence customers directly or indirectly. This created an interest in exploring the demographic profile and the key factors influencing consumer buying behavior.

The study covers both the primary and secondary/tertiary data. Primary data was collected by a survey method through a structured questionnaire. Customers in different occupations and different age groups, which include students, business people and professional, were contacted directly to get first-hand information.

For the purpose of the study, the data has been collected at South Delhi region. 100 respondents including male and female were 
randomly selected for the study as sample. The explanation is given in data analysis. A population of the study includes all the customers/consumers in the age group of 18 to 26 years and above at South Delhi region. The primary survey was conducted during the month of December 2012 - January 2013.

A preliminary questionnaire, consisting of 16 questions based on the review of literature and discussion, was developed. To identify the important attributes, the questionnaire was pre-tested by personally interviewing 10 respondents. Editing followed this exercise, where problems identified during the pre-testing were rectified.

After reviewing the pre-tested questionnaire it was decided to confine the research to 11 questions and a new questionnaire was designed. The components in the questionnaire were fine-tuned keeping in view the experiences the researcher gained while conducting the survey. A total of 100 completed questionnaires were collected, and all were finally used for further analysis.

The data collected from the primary sources were analyzed with the help of various statistical measures such as Chi square tests; Regression analysis and Paired t-test were also used.

\section{Literature Review}

Mullin, Hardy and Sutton (2007) have pointed out that sponsorship is the purchase of privileges to directly connect with a product, brand, experience and event for the intention of originating benefits related to that involvement. Dolphin (2003) has recommended quite a few idea that the organization should opt to make a decision to penetrate into a sponsorship such as

1. Augment the corporate image

2. Raise brand awareness among customers

3. Encourage and will aid in sales

4. Corporate reputation for the firm

5. Modify customer perception

6. Make relationships with the customer

7. Create goodwill about the company among customer

8. Increase the motivation of internal employee 
Amis et al. (1999) indicated that efficiently controlled sponsorships can be a unique ability for a company which in turn enables the supporter to achieve a competitive advantage. Strategic role of sponsorship assists companies to classify the two unique echelon of competitive advantage. Firstly, there is the accomplishment of improvement in the competitive marketplace for sponsorship. Secondly, concern of competitive advantage in product or brand markets of the company.

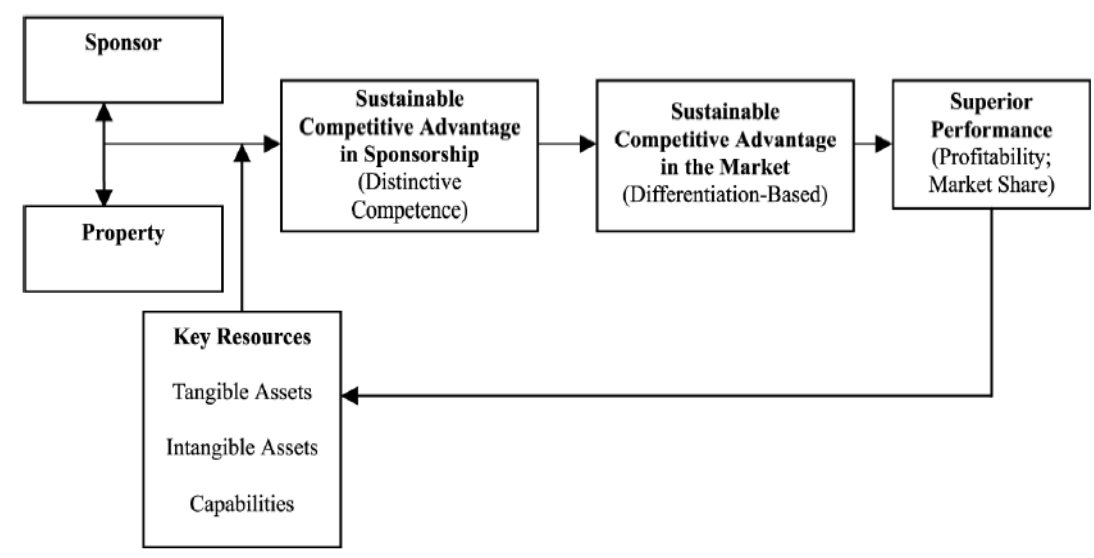

Fig 1: A model of sponsorship-based competitive advantage

(Source: Fahy et al. (2004), Competitive advantage through Sponsorship A conceptual model and research propositions, European Journal of Marketing, Vol. 38 No. 8, pp. 1013-1030)

Sponsorship directs companies to achieve distinctive competence and differentiation or product uniqueness in the market (refer to Figure 1). At the same time sponsorship facilitate to attain superior performance in terms of profitability and market share (refer to Figure 1). Fahy et al. (2004) revealed that for sponsorship three key resources are required: Tangible assets, Intangible assets, Capabilities (refer to Figure 1). Companies hunt for substantial benefits from different sponsorship program including publicity, product sampling, awareness creation, increase in sales, networking, signage rights, merchandising, client entertainment, and media coverage (Geldard, E. \& Sinclair, L.; 2002). Publicity is the most dominant way to introduce an innovative and fresh 
product or technology in the market. Publicity is more reliable as well as less cost-effective than advertising. A sponsorship is the essential lever for a firm to promote the information and value of a product of latest technology to become the front-page cover of the news. Product visibility will easily increase the association of the brand of a firm and an event that has been sponsored by the individual firm (Aaker \& Joachimsthaler 2000). Meenaghan (1994) indicated in his research that sponsorship is an investment in the team, player or an event to associate commercially to increase the visibility and top line of the company.

Sponsorship has become the foundation of the entire marketing strategy (Meenaghan, 1998), termed as "sponsorship-linked marketing" (Cornwell, 1995). Observation of fact indicates that sponsorship decision makers of any company are habitually senior managers (Burton et al., 1996). For example, the sponsorship in a Twenty20 Indian Premier League involves contract with cricket teams and players. Brands such as Coca Cola with the Olympic Games or Pepsi with World Cup Cricket reflect as well as strengthen the global stature of these brands. Sponsorship has the possibility to excel in cultural boundaries and as a result have become the device of option for international marketers (Cunningham et al., 1993; Miyazaki and Morgan, 2001). During the 2011 World Cup Cricket, PepsiCo held a highly visible place as sponsor of India cricket team. PepsiCo had played the role of the official beverage and snacks partner. Reebok, the popular apparels and footwear brand, was the official partner in 2011 world cup cricket tournament and at the same time has endorsed many players such as Mahela Jayawardene, Shoaib Malik, VVS Laxman, Mahendra Singh Dhoni, Chris Gayle and so on.

Corporate image and reputation are highly valuable for an organization which runs business across geographic. The key job of marketing or brand managers is to promote the business as well as to increase the reputation and image of the company. Sport sponsorship can be a precious and cost-effective tool with which a firm can enlarge the corporate image and reputation if implemented prudently (McDonald, 1991). Therefore, sponsorship is viewed as a precious resource with the prospective of realizing sustainable advantage. 


\section{Findings of the Study}

\section{Paired Sample T- Test}

Analysis 1: Preference Analysis of live telecast as a method of sports sponsorship

Null Hypothesis $\left(\mathrm{H}_{0}\right)=$ There is no effect of live telecast sports sponsorship on brand image and competitive advantage

Alternate Hypothesis $\left(\mathrm{H}_{1}\right)=$ There is an effect of live telecast sports sponsorship on brand image and competitive advantage.

Since the level of significance is less than 0.05 , it signifies the failure to accept the null hypothesis and have to accept alternate hypothesis. The mean attitude towards the live telecast is 4.05 (refer to Table 1(a)), and mean difference between the variable is -2.97 with the standard deviation of 1.19 (refer to Table 1(b)). Accordingly the t-value is -15.848 (refer to Table 1(b)). It has been seen from the analysis that the mean response is large and standard deviation is not too large. So it can be concluded that the respondents have a more favorable attitude towards live telecast of sports sponsorship.

Table 1(a): Paired Samples Statistics for live telecast

\begin{tabular}{|c|c|c|c|c|c|}
\hline & & Mean & $\mathrm{N}$ & $\begin{array}{c}\text { Std. } \\
\text { Deviation }\end{array}$ & $\begin{array}{c}\text { Std. Error } \\
\text { Mean }\end{array}$ \\
\hline Pair 1 & $\begin{array}{c}\text { Do you feel that } \\
\text { company should } \\
\text { go for sports } \\
\text { sponsorship }\end{array}$ & 1.08 & 100 & .27 & 4.22E-02 \\
\hline
\end{tabular}


Table 1(b): Paired Samples Statistics for live telecast

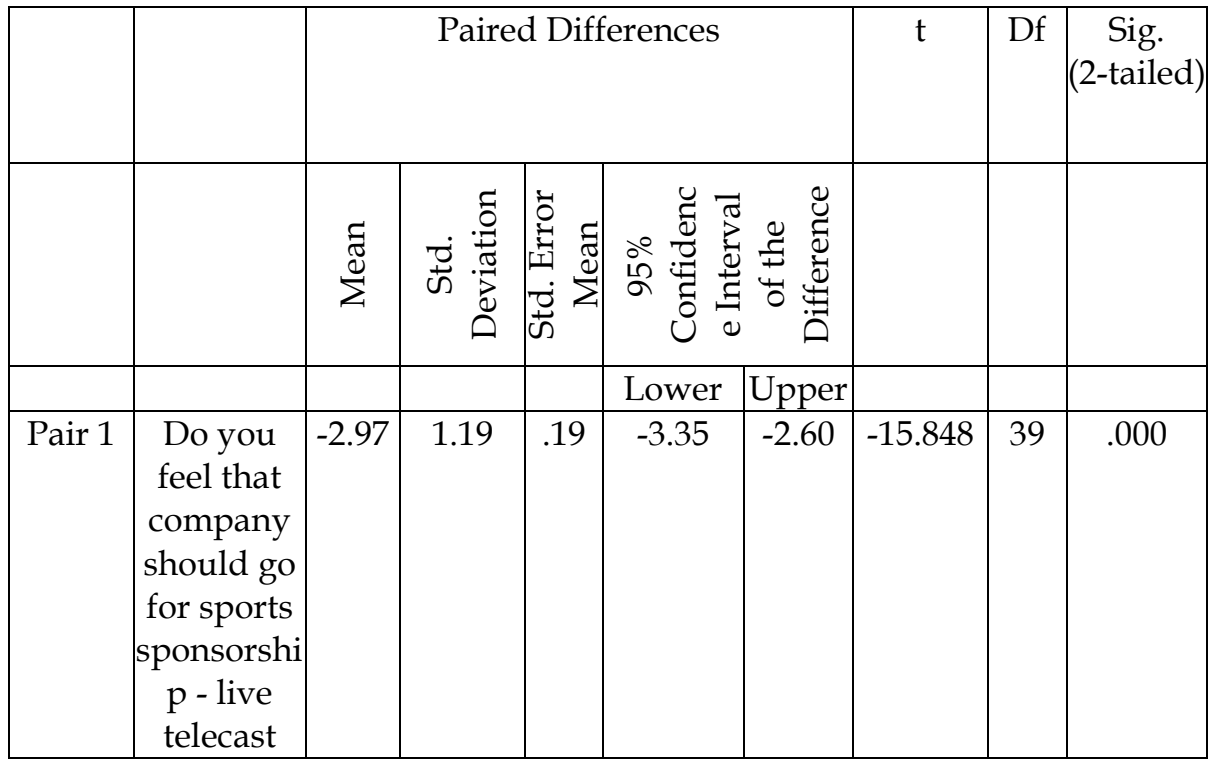

Source: Primary Data $(\mathrm{N}=100)$

\section{Analysis 2: Preference Analysis of Hoarding as a method of sports sponsorship}

Null hypothesis $(\mathrm{HO})=$ There is no effect of hoardings sports sponsorship on the brand image and competitive advantage

Alternate Hypothesis $(\mathrm{H} 1)$ = There is an effect of hoardings sports sponsorship on the brand image and competitive advantage

The analysis result shows that $t$-value $=-15.24$ and the level of significance is less than 0.05 (refer to Table 2(b)). As a result, the null hypothesis of no differences is rejected. The mean attitude towards the hoarding is 3.25 (refer to Table 2(a)), and the mean differences between the variable is -2.17 with the standard deviation of 0.90 (refer to Table 2(b)). Given that the mean responses is large and standard deviation is not too large but more than live telecast sports sponsorship, it signifies that there is more variation in responses regarding the choice of hoarding among the respondent. So it is advisable for the company to be cautious while going for sports sponsorship through hoardings. 
Table2(a): Paired Samples Statistics for Hoardings

\begin{tabular}{|c|c|c|c|c|c|}
\hline & Mean & N & $\begin{array}{c}\text { Std. } \\
\text { Deviation }\end{array}$ & $\begin{array}{c}\text { Std. } \\
\text { Error } \\
\text { Mean }\end{array}$ \\
\hline Pair 1 & $\begin{array}{c}\text { Do you feel that company should } \\
\text { go for sports sponsorship }\end{array}$ & 1.08 & 100 & .27 & $4.22 \mathrm{E}-02$ \\
\hline & Hoardings & 3.25 & 100 & .87 & .14 \\
\hline
\end{tabular}

Source: Primary Data $(\mathrm{N}=100)$

Table 2(b): Paired Samples Statistics for Hoardings

\begin{tabular}{|c|c|c|c|c|c|c|c|c|c|}
\hline & & \multicolumn{5}{|c|}{ Paired Differences } & \multirow[t]{2}{*}{$\mathrm{T}$} & \multirow[t]{2}{*}{$\mathrm{df}$} & \multirow{2}{*}{$\begin{array}{l}\text { Sig. (2- } \\
\text { tailed) }\end{array}$} \\
\hline & & 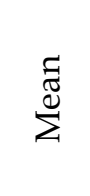 & 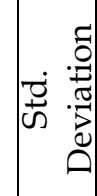 & 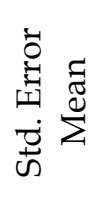 & \multicolumn{2}{|c|}{ 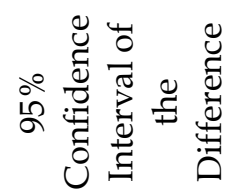 } & & & \\
\hline & & & & & Lower & Upper & & & \\
\hline Pair 1 & $\begin{array}{l}\text { Do you feel } \\
\text { that } \\
\text { company } \\
\text { should go } \\
\text { for sports } \\
\text { sponsorship } \\
\text { - Hoardings }\end{array}$ & -2.17 & .90 & .14 & -2.46 & -1.89 & -15.240 & 39 & .000 \\
\hline
\end{tabular}

Source: Primary Data $(\mathrm{N}=100)$

Analysis 3: Preference Analysis of Advertisement as a method of sports sponsorship

Null hypothesis $(\mathrm{H} 0)=$ There is no effect of sports sponsorship advertisement on the brand image and competitive advantage

Alternate hypothesis $(\mathrm{H} 1)=$ There is an effect of sports sponsorship advertisement on the brand image and competitive advantage

Since the level of significance is less than 0.05 and $t$-value $=-19.19$ (refer to Table 3(b)). As a consequence, the null hypothesis of no 
differences is rejected. The mean attitude towards the advertising is 3.98 (refer to Table 3(a)), and the mean differences between the variable is -2.90 with the standard deviation of 0.96 (refer to Table $3(b))$. In view of the fact that, the mean response is larger than the mean response of hoarding, the standard deviation is not high. As a result, it can be concluded that companies should prefer advertising as an approach of sports sponsorship rather than going for hoarding, keeping in mind the budget constraint.

Table 3(a): Paired Samples Statistics for Advertisement

\begin{tabular}{|c|c|c|c|c|c|}
\hline Pair 1 & Mean & $\mathrm{N}$ & $\begin{array}{c}\text { Std. } \\
\text { Deviation }\end{array}$ & $\begin{array}{c}\text { Std. Error } \\
\text { Mean }\end{array}$ \\
\hline & $\begin{array}{c}\text { Do you feel that } \\
\text { company should go } \\
\text { for sports } \\
\text { sponsorship }\end{array}$ & 1.08 & 100 & .27 & $4.22 \mathrm{E}-02$ \\
\hline & Advertisements & 3.98 & 100 & .89 & .14 \\
\hline
\end{tabular}

Source: Primary Data $(N=100)$

Table 3(b): Paired Samples Statistics for Advertisement

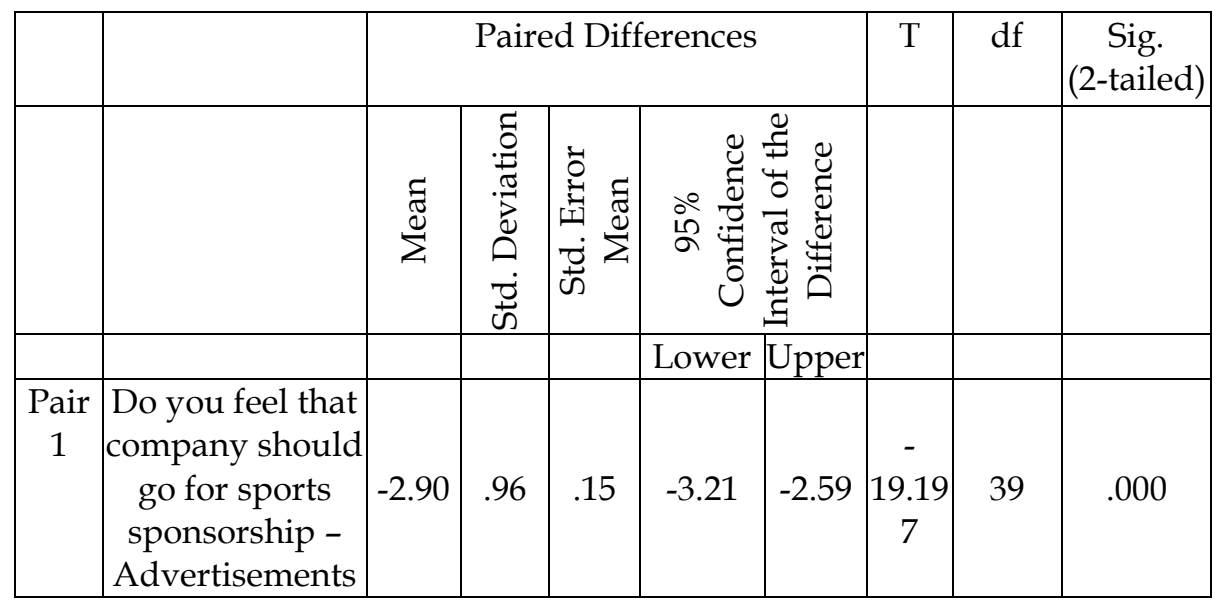

Source: Primary Data $(N=100)$ 


\section{Analysis 4: Preference Analysis of Radio as a method of sports sponsorship}

Null hypothesis $(\mathrm{H} 0)=$ There is no effect of Radio as a sports sponsorship on the brand image and competitive advantage

Alternate hypothesis (H1) $=$ There is an effect of Radio as a sports sponsorship on the brand image and competitive advantage

The result have indicated that $t$-value $=-10.95$ and the level of significance is less than 0.05 (refer to Table 4(b)). It signifies about the rejection of null hypothesis and has to accept alternate hypothesis. The mean attitude towards the radio as a means of sports sponsorship is 3.08 (refer to Table 4(a)), which is quite low as compared to the advertising, and the mean differences between the variables are -2.00 with the std. deviation of 1.15 (refer to Table $4(\mathrm{~b}))$.

Since the mean response is slightly less than the mean response for advertising and the standard deviation is quite high as compared to other means. So, it can be concluded that the company should be very careful while selecting radio as a sports sponsorship technique because it may be not as effective as compared to other method.

Table 4(a): Paired Samples Statistics for Radio

\begin{tabular}{|l|l|c|c|c|c|}
\hline & Mean & $\mathrm{N}$ & $\begin{array}{c}\text { Std. } \\
\text { Deviation }\end{array}$ & $\begin{array}{c}\text { Std. Error } \\
\text { Mean }\end{array}$ \\
\hline Pair 1 & $\begin{array}{l}\text { Do you feel that company } \\
\text { should go for sports } \\
\text { sponsorship }\end{array}$ & 1.08 & 100 & .27 & $4.22 \mathrm{E}-02$ \\
\hline & Radio & 3.08 & 100 & 1.10 & .17 \\
\hline
\end{tabular}

Source: Primary Data $(\mathrm{N}=100)$ 
Table 4(b): Paired Samples Statistics for Radio

\begin{tabular}{|c|c|c|c|c|c|c|c|c|c|}
\hline & & \multicolumn{5}{|c|}{ Paired Differences } & \multirow[t]{2}{*}{$\mathrm{T}$} & \multirow[t]{2}{*}{$\mathrm{df}$} & \multirow{2}{*}{$\begin{array}{c}\text { Sig. } \\
(2- \\
\text { tailed) }\end{array}$} \\
\hline & & $\underset{\mathbb{\Xi}}{\stackrel{\Xi}{\Sigma}}$ & 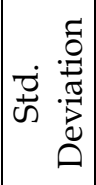 & 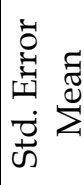 & \multicolumn{2}{|c|}{ 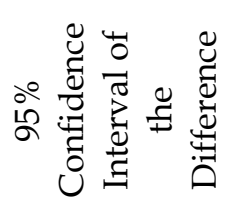 } & & & \\
\hline & & & & & Lower & Upper & & & \\
\hline Pair 1 & $\begin{array}{c}\text { Do you feel } \\
\text { that } \\
\text { company } \\
\text { should go } \\
\text { for sports } \\
\text { sponsorship } \\
\text { - Radio }\end{array}$ & -2.00 & 1.15 & .18 & -2.37 & -1.63 & -10.954 & 39 & .000 \\
\hline
\end{tabular}

Source: Primary Data $(\mathrm{N}=100)$

Analysis 4: Regression Analysis of the effect of endorsing sports celebrity on the buying behavior of the consumer.

Null Hypothesis (H0): There is no linear relationship between endorsing sports celebrity and buying behavior

Alternate Hypothesis (H1): There is a linear relationship between endorsing sports celebrity and buying behavior

\section{Regression Equation}

Buying Behavior $=1.79+0.34$ endorsement +1.14 std. error $($ refer to Table 5,7)

It has been seen from the regression equation that the constant value is 1.79 which signifies that the consumer's buying behavior will increase by $1.7 \%$ even if the companies don't opt for endorsing sports celebrity. While the slope 0.34 indicates that with every 1 rupee spent on endorsement the buying behavior of the consumer will increase by $34 \%$.As coefficient of determination $\mathrm{R}^{\wedge} 2$ is 0.089 indicates that $8.9 \%$ of the variation in the consumer buying 
behavior can be explained by the variation in endorsement with standard error of 1.14 (refer to Table 5). Hence, it can be believed that $29.9 \%$ of the variation in the buying behavior can be explained by the linear regression model- adjusted for number of predictors and sample size (refer to Table 5).

Table 5: Model Summary

\begin{tabular}{|c|c|c|c|c|}
\hline Model & $\mathrm{R}$ & $\mathrm{R}$ Square & $\begin{array}{c}\text { Adjusted R } \\
\text { Square }\end{array}$ & $\begin{array}{c}\text { Std. Error of } \\
\text { the Estimate }\end{array}$ \\
\hline 1 & .299 & .089 & .065 & 1.14 \\
\hline
\end{tabular}

Source: Primary Data $(\mathrm{N}=100)$

a Predictors: (Constant), Do you prefer the brand which is endorsed by any sports celebrity

Table 6: ANOVA

\begin{tabular}{|c|l|r|r|r|r|r|}
\hline Model & & $\begin{array}{c}\text { Sum of } \\
\text { Squares }\end{array}$ & Df & $\begin{array}{c}\text { Mean } \\
\text { Square }\end{array}$ & F & Sig. \\
\hline 1 & Regression & 4.809 & 1 & 4.809 & 3.723 & .061 \\
\hline & Residual & 49.091 & 38 & 1.292 & & \\
\hline & Total & 53.900 & 39 & & & \\
\hline
\end{tabular}

a. Predictors: (Constant), Do you prefer the brand which is endorsed by any sports celebrity

b. Dependent Variable: Does sports sponsorship affect your buying behaviour

Source: Primary Data $(\mathrm{N}=100)$ 
Table 7: Coefficients

\begin{tabular}{|c|c|c|c|c|c|c|}
\hline & & $\begin{array}{c}\text { Un- } \\
\text { standardized } \\
\text { Coefficients }\end{array}$ & & $\begin{array}{c}\text { Standardized } \\
\text { Coefficients }\end{array}$ & $\mathrm{t}$ & Sig. \\
\hline Model & & $\mathrm{B}$ & Std. Error & Beta & & \\
\hline 1 & (Constant) & 1.795 & .675 & & 2.661 & .011 \\
\hline & $\begin{array}{l}\text { Do you } \\
\text { prefer the } \\
\text { brand } \\
\text { which is } \\
\text { endorsed } \\
\text { by any } \\
\text { sports } \\
\text { celebrity }\end{array}$ & .348 & .181 & .299 & 1.929 & .061 \\
\hline
\end{tabular}

a. Dependent Variable: Does sports sponsorship affect your buying behavior

Source: Primary Data $(\mathrm{N}=100)$

\section{Respondents View on Sports Sponsorship}

Most of the respondents agree that the companies should go for sports sponsorship, i.e., $92 \%$ respondents agreeing that sports sponsorship will enhance the brand image and competitive advantage (refer to Figure 2).

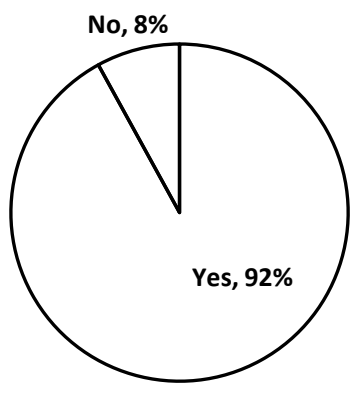

Fig 2: Respondents View on Sports Sponsorship 


\section{Conclusion}

Sport-sponsorship is used by the companies to create the brand awareness for their products. Several companies such as Coca Cola, Pepsi, Adidas, LG and Hero Honda have invested on participating teams, players or an event. Sponsorship helps companies to get unique competence for their product in the market.

Literature research indicates on the increase in brand awareness of a firm among customers due to sports-sponsorship. The research has identified that attributes such as live telecast, advertising, hoarding or radio have more or less impact upon the buying behavior of the consumer and these attributes will facilitate the company to position its brand image. But the strengthens of their impact varies among different attributes. Attributes like live telecast and advertisement may be more considerable for the company due to preference of these attributes among consumers. Therefore, it is advisable for the company to opt for these attributes to enhance the brand image and increase competitive advantage. The Research highlights the relationship between endorsing sports celebrity and consumer buying behavior. The research concludes that most of the respondents agree that sports sponsorship will enhance the brand image and competitive advantage.

\section{Recommendations}

Some of the research findings and the recommendations are as follows:

1. The companies should go more for live telecast sports sponsorship because through this long term positioning in the minds of the consumer is possible.

2. The company should go for attractive hoardings by endorsing the sports celebrity as this will also enhance the brand image and competitive advantage.

3. The company should not go for radio as a method for sports sponsorship because it will not be helpful for the company who wants to create brand image. The option for radio as a method of sports sponsorship should be done by those 
companies who have more customers concentrated in the rural areas.

\section{Limitations and Caveats}

- The sample size is limited to 100 respondents in south Delhi region. The sample size may not adequately represent the national market.

- As the sampling technique used is convenience sampling, the sample may not give the exact replica of the universe.

- This study was not conducted over an extended period of time; it was conducted over a period of two month. Hence it may be difficult to analyze the consumer behavior in just two month.

\section{References}

Aaker, D. A., \& Joachimsthaler, E. (2000). Brand Leadership, Free Press, 2002.

Amis, J., Slack, T. \& Berrett, T. (1999). Sport sponsorship as distinctive competence. European Journal of Marketing, 33, 14-25.

Burton, R., Quester, P. \& Farrelly, F. (1996). Organizational power games: decisions in sports sponsorship investment. Marketing Management, 7, 6-15.

Cornwell, B. (1995). Sponsorship-linked marketing development. Sports Marketing Quarterly, 4, 13-24.

Cunningham, P., Taylor, S. \& Reeder, C. (1993). Event marketing: The evolution of sponsorship from philanthropy to strategic promotion. Proceedings of the 6th Conference on Historical Research in Marketing and Marketing Thought, Michigan State University, East Lansing, MI.

Dolphin, R. (2003). Sponsorship: Perspectives on its strategic role. An International Journal, 8(3), 173-186.

Fahy, et al. (2004). Competitive advantage through sponsorship: A conceptual model and research propositions. European Journal of Marketing, 38(8), 1013-1030.

Geldard, E. \& Sinclair, L. (2002). Introduction to Sponsorship. The Sponsorship Unit Pty Ltd., Australia 
McDonald, C. (1991). Sponsorship and the image of the sponsor. European Journal of Marketing, 25(11), pp. 31-38.

Meenaghan, A. (1991). The role of sponsorship in the marketing communications mix. International Journal of Advertising, 10, 35-47.

Meenaghan, T. (1994). Point of view: Ambush marketing: Immoral or imaginative practice? Journal of Advertising Research, 34, 77-88.

Meenaghan, T. (1998). Current developments and future directions in sponsorship. International Journal of Advertising, 17, 3-28.

Mintel. (1994). Sports Sponsorship. London: Mintel International Group Limited.

Miyazaki, A. D. and Morgan, A. G. (2001). Assessing market value of event sponsorship: Corporate Olympic sponsorships. Journal of Advertising Research, 41(1), 9-15.

Mullin, Bernard J., Hardy, Stephen \& Sutton, William A. (2007). Sport Marketing, 3rd ed. Champaign: Human Kinetics, cop. 2007.

Witcher, B., Craigen, J. G., Culligan, D., \& Harvey, A. (1991). The links between objectives and function in organizational sponsorship. International Journal of Advertising, 10, 13-33. 